RESEARCHARTICLE

\section{Advancing Effective Leaders: An Example of the Management Education at the US Coast Guard Academy}

\author{
Alina M. Zapalska, Mike McCarty, Kimberly C. Young-McLear, and Tyler Kelley \\ Department of Management, U.S. Coast Guard Academy New London, CT 06320 USA
}

\begin{abstract}
Effective leaders are essential to the success of their organizations. As organizations require leaders who are professionally ready, business academic programs are responsible for educating their students to be able to effectively lead across cultural, religious, political, and organizational boundaries. This paper presents an academic strategy for leadership development that was advanced by the Department of Management at the United States Coast Guard Academy. According to the program's goals, students are expected to discover and master their own leadership style as well as to advance businesses competencies, critical thinking, and communication skills. The strategy of professional development must be advanced over four years of undergraduate study in order to produce leaders who will effectively fulfill the mission of their own organization.
\end{abstract}

\section{Keywords}

Open Access

Citation: Zapalska, A.M., McCarty, M., Young-McLear, K. C., Kelley, T. (2017). Advancing Effective Leaders: An Example of the Management Education at the US Coast Guard Academy. Interdisciplinary Education and Psychology, 1(1):2.

Received: June 06, 2017

Accepted: July 12, 2017

Published: July 24, 2017

Copyright: ๑ 2017 Zapalska et al. This is an open access article distributed under the terms of the Creative Commons Attribution License, which permits unrestricted use, distribution, and reproduction in any medium, provided the original author and source are credited.

Corresponding author: Alina M. Zapalska, Department of Management, U.S. Coast Guard Academy New London, CT 06320 USA. E-mail: Alina.M.Zapalska@uscga.edu
Leadership, self-leadership, educational strategies, business major, organizational success

\section{Introduction}

Today, successful organizations recognize the importance of effective leadership. As the world has been changing fast, the behavioral characteristics of leaders in organizations must respond to those changes. In order to address this, academic programs have been focusing on creating educational programs that prepare future leaders who are able to solve social, political, economic, and environmental problems (Uhl-Bien, 2007). Addressing challenges of terrorism, climate change, and societal injustice presents enormous tasks today. Maellaro (Maellaro, 2013) argues that academic institutions respond to these challenges by developing educational programs that produce responsible citizens and effective leaders.

Leadership education has been a goal of academic programs for many years and many approaches have been proposed to produce fairly effective educational models for developing leaders of the 21 st century (Sowcik and Allen, 2013). The leadership education must be revised over time to adequately prepare leaders for an increasingly challenging environment and to develop leaders who demonstrate effective strategies in their actions in order to obtain the best performance of their organizations within specific cultural, social, political, and economic situations (Maellaro, 2013).

This paper presents an educational leadership development approach that has been advanced at the U.S. Coast Guard Academy (USCGA). The process of leadership skills development at USCGA has been attained through both the curricular and extra-curricular programs with an emphasis on self-leadership, business competencies, communication, critical thinking, and information literacy (IL) skills advancement. These five leadership skills demonstrate competencies that effective CG leaders must acquire in order to successfully lead and execute $C G$ missions. 


\section{Literature Review}

Researchers have discussed the importance of leadership strategies in bringing innovation and organizational effectiveness to business organizations (Kaiser et al., 2008). Effective leaders are those individuals who can deliver desired changes in cultural climate, organizational structure, and governance process within their organizations (Tarabishy et al., 2005). Organizations need leaders who are innovative and able to embrace changes and uncertainty in an increasingly challenging environment (Northouse, 2007). Successful leaders provide clear direction, vision, drive, and motivation for their organizations and enhance organizational performance by increasing employees' satisfaction and improving employees' motivation (Papalexandris and Galanaki, 2009). Kouzes and Posner argue that leadership works when values are understood and aligned with actions, and true leaders take actions to create the world they desire to live in and influence their followers to operate a like (Kouzes and Posner, 2011).

An approach to the leadership education consists of the examination of leader and follower requirements and characteristics as well as an analysis of strategies on how to develop various skills so that leaders will effectively communicate, engage, build trust, influence, and understand people and their motivations while leading their organizations (Thayer, 1988). Manz and Smith contend that individuals should be trained in self-leadership so they can lead themselves first before they start leading others within their organizations (Manz and Smith, 2001). Leadership is the "process of influencing the activities of an organizational group in the efforts toward goal setting and achievement" (Stogdill and Bass, 1981, p. 9.), while the term self-leadership is defined as "a process of influencing oneself to achieve the self-direction and self-motivation necessary to behave and perform in desirable ways" (Houghton and Neck, 2002, p.1).

Academic institutions' integration of leadership theory with real-world practices has gained a fundamental role in formatting the excellence of self-leadership (Prussia et al., 1998) and leadership education (Maellaro, 2013). Neck (1996) indicates that self-leadership is critical to organizational effectiveness as efficient self-leaders are more dynamic and better prepared to bring organizational change that increases productivity and fosters technological innovation. The authors argue that self-leadership education must be based on the advancement of professional competencies, communication, critical thinking, and leadership growth where the personal integration of theory is mixed with practice and real-life experiences and training (Brown and Posner, 2001).

Military organizations' leadership models and instructional programs train and prepare leaders from the entry level to the flag officer rank who are trained to effectively lead their organizations (Taylor and Rosenbach, 2005). Their leadership skills are built upon organizational values, principles and ideologies that create justice, equity, respect, integrity, stability, and community within their organizations (Kaiser et al., 2008).

This paper builds on this research to argue that the development of leadership by itself does not lead to effective advancement of leadership skills. It is essential to establish a program that embraces the development of strong and organization-based self-leadership skills that are based on five learning objectives: leadership, communication, business competences, critical thinking, and information literacy skills. The strategy of leadership development advanced by the USCGA's Management Department represents a model that can be adopted by other undergraduate programs that plan to produce effective leaders of the 21 st century.

\section{Background on the USCGA and Leadership Educational Strategy at the USCGA}

The USCGA is a public institution aimed at providing an undergraduate education, and physical and military training to the cadets who will serve as leaders in the United States Coast Guard (USCG). The Academy's mission is to: educate, train, and develop leaders of character who are ethically, morally, intellectually, and professionally prepared to serve their country and humanity. In order to meet these goals, the Academy's holistic education delivers academic, physical fitness, ethical, character and leadership development programs. As military professionals, the USCGA cadets are expected to be responsible for their own behavior, hold others accountable, and to display devotion to the mission of the USCG and the Department of Homeland Security. 
Table 1. The USCG Academy and Management Department Learning Goals

\begin{tabular}{|c|c|}
\hline $\begin{array}{l}\text { United States Coast Guard Academy } \\
\text { Shared Learning Outcomes }\end{array}$ & $\begin{array}{l}\text { Department of Management } \\
\text { Learning Outcome Areas }\end{array}$ \\
\hline $\begin{array}{l}\text { Leadership, Abilities: Graduates shall be military and } \\
\text { civilian leaders of character who understand and } \\
\text { apply sound leadership principles and competencies. } \\
\text { This includes the ability to direct, develop, and } \\
\text { evaluate diverse groups; to function effectively and } \\
\text { ethically as aleader, follower, facilitator or member } \\
\text { of a team; and to conduct constructive assessment of } \\
\text { self and others. }\end{array}$ & $\begin{array}{l}\text { Leadership: Graduates of the Management major } \\
\text { shall be leaders of character who understand and } \\
\text { demonstrate sound leadership principles and } \\
\text { competencies. Graduates shall function effectively } \\
\text { as leaders, followers, and facilitators. Graduates } \\
\text { shall be able to conduct critical self-reflection and } \\
\text { assessment. Graduates shall be able to direct, } \\
\text { develop, and evaluate diverse individuals and } \\
\text { goups. }\end{array}$ \\
\hline $\begin{array}{l}\text { Personal and Professional Qualities: Graduates shall } \\
\text { maintain a professional lifestyle that embraces the } \\
\text { Coast Guard Core Values of Honor, Respect and } \\
\text { Devotion to Duty, includes physical fitness and } \\
\text { wellness, and demonstrates the customs, courtesies } \\
\text { and social skills befitting members of a mantime } \\
\text { military service. Graduates shall also have a sense of } \\
\text { Coast Guardmanitime heritage and anunderstanding } \\
\text { of the roles that the Coast Guard and the nation play } \\
\text { in the global environment. }\end{array}$ & $\begin{array}{l}\text { Information Literacy: Graduates of the } \\
\text { Management major shall be leaders who possess } \\
\text { the ability to know when there is a need for } \\
\text { information, to be able to identify, locate, evaluate } \\
\text { and effectively use that information for the issue } \\
\text { or problem at hand. }\end{array}$ \\
\hline $\begin{array}{l}\text { Communurication Effectiveness: Graduates shall be } \\
\text { able to write clearly, concisely, persua sively, and } \\
\text { grammatically; prepare and deliver well-organized } \\
\text { and polished oral presentations; read and understand a } \\
\text { vanety of writen materials; isten thoughtfully to oral } \\
\text { argments; respect diverse opinions; and formulate } \\
\text { reasoned altematives andresponses. }\end{array}$ & $\begin{array}{l}\text { Comumunication: Graduates of the Management } \\
\text { major shall be good listeners. Graduates shall be } \\
\text { able to write clearly, concisely, and effectively. } \\
\text { Graduates shall be able to deliver effective } \\
\text { practiced, professional oral presentations and be } \\
\text { able to speak confidently extemporaneouly. }\end{array}$ \\
\hline 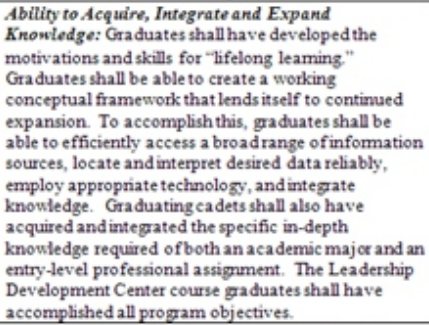 & $\begin{array}{l}\text { Business Competence: Graduates of the } \\
\text { Management major shall understand and } \\
\text { demonstrate the following business competencies: } \\
\text { (a) accounting, (b) economics, (c) management, } \\
\text { (d) quantitative analysis, (e) finance, (f) } \\
\text { marketing, (g) intemational issues, (h) legal and } \\
\text { social environment issues, and (d) management of } \\
\text { information systems. }\end{array}$ \\
\hline $\begin{array}{l}\text { Critical Thinking Ability: Graduates shall be able to } \\
\text { accomplish complex tasks in a broadrange of } \\
\text { contexts by applying the basic skills of critical } \\
\text { analysis, systems thinking, quantitative reasoning. } \\
\text { risk management, creative problem solving, and } \\
\text { value-based decision-making }\end{array}$ & $\begin{array}{l}\text { Critical Thinking: Graduates of the Managemert } \\
\text { major shall be able to effectively integrate their } \\
\text { knowledge and skills of inleadership, } \\
\text { commumications, technology, and business } \\
\text { competencies into a rational decision-making and } \\
\text { problem-solving framework. }\end{array}$ \\
\hline
\end{tabular}

\section{Source: Developed by Department of Management, USCGA.}

The Academy's academic program offers Bachelor of Science degrees in eight majors that include: Civil Engineering, Electrical Engineering, Mechanical Engineering, Naval Architecture and Marine Engineering, Government, Management, Operations Research and Computer Analysis, and Marine and Environmental Science. The Academy delivers undergraduate academic course work that is supported through required courses within humanities, science, engineering, mathematics, maritime studies, organizational behavior, management, and law. The Department of Management at the USCGA delivers an undergraduate education in management where Management majors are expected to develop and master business competencies, communication, self-leadership, critical thinking, and information literacy skills. These skills, as illustrated in Table 1, are closely related to the shared learning outcomes across all majors at the USCGA.

\section{Leadership Competencies}

The leadership competencies, that USCGA cadets are required to develop, are presented in Figure 1. Leadership development is divided into four categories: leading self, leading others, leading performance and change, and leading the Coast Guard. These four categories consist of several competencies, including team building, communications, accountability, conflict management, and technical proficiency, which cadets must develop over four years at USCGA. With each progressive year, cadets shift their focus to the next set of competencies, while still sharpening their skills in the previous categories. To achieve these competencies, the USCGA approach uses three groups of activities or basic components: academics, non-academics (includes military and athletics), and professional practice (community and service learning, cadet organizations, and clubs) as presented in Figure 2. 
Figure 1. USCGA's Leadership Development Framework

\begin{tabular}{|c|c|c|}
\hline LEADERSHIP CATEGORIES & & LEADERSHIP COMPETENCIES \\
\hline 2 & & 18 \\
\hline $\begin{array}{l}\text { LEADING SELF } \\
\text { (Freshman year) }\end{array}$ & Q & $\begin{array}{l}\text { Accountability and responsibility, aligning values, } \\
\text { followership, health and well-being, self-awareness, } \\
\text { personal conduct, technical proficiency }\end{array}$ \\
\hline $\begin{array}{l}\text { LEADING OTHERS } \\
\text { (Sophomore and beyond) }\end{array}$ & Qस्थय & $\begin{array}{l}\text { Effective communications, team building, influencing } \\
\text { others, taking care of people mentoring, respect for } \\
\text { others \& diversity, management }\end{array}$ \\
\hline $\begin{array}{l}\text { LEADING PERFRORMANCE } \\
\text { AND CHANGE } \\
\text { (Sophomore and beyond) }\end{array}$ & eparas & $\begin{array}{l}\text { Conflict management, customer focus, decision making } \\
\text { and problem solving, management and process } \\
\text { improvement, vision development and implementation, } \\
\text { creativity and innovation }\end{array}$ \\
\hline $\begin{array}{l}\text { LEADING } \\
\text { THE COAST GUARD } \\
\text { (Sophomore and beyond) }\end{array}$ & Qpom & $\begin{array}{l}\text { Financial management, technology management, human } \\
\text { resource management, external awareness, political } \\
\text { savvy, partnering entrepreneurship, stewardship, } \\
\text { strategic thinking }\end{array}$ \\
\hline
\end{tabular}

Source: Commandant Instruction COMDTINST M5351.3, Leadership Development Framework, USCG, 2006.

During freshman year, cadets are expected to develop competences in the leading self category. Through a self-discovery process, cadets study strengths and weaknesses of political, historical, military, and entrepreneurial role-models. For example, during their freshman year cadets are required to take English Composition and Speech, and Writing about Literature, and Leaders in US History. In Leaders in US History, cadets study the most important developments in US History through the role of key leaders and are exposed to models of effective and ineffective leadership practices. The two English courses develop information literacy, critical thinking, and communication skills that are reinforced throughout the remaining Management curriculum. CGA cadets also take a wide variety of courses outside of their specific major to widen their perspective, encourage self-criticism and discovery, and develop CG professional skills.

Figure 2. Advancement of Leadership Skills at the USCGA.

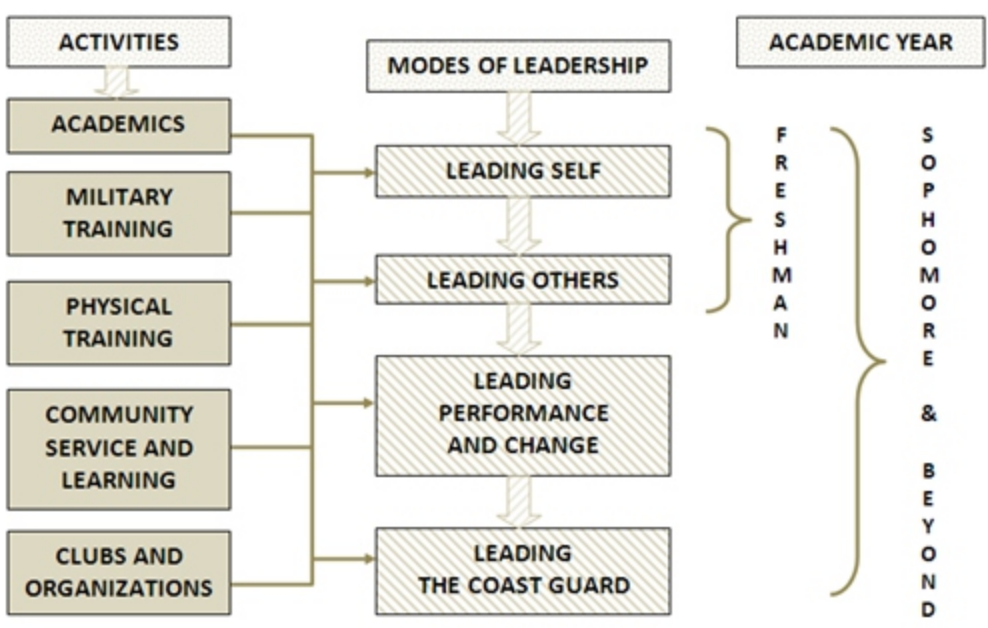

Source: Developed by authors.

During the sophomore year, cadets take Leadership and Organizational Behavior and American Government. In the Leadership and Organizational Behavior course cadets study leadership and management concepts and focus on development of moral values, leadership and personality characteristics, self-awareness, working in teams, motivation, and setting a vision with particular emphasis on practical leadership implications. In American Government, they study the relationship between the local, state, and federal government agencies and focus on leading self but leading others through understanding of the political process, the creation of public policy, and the framework of the U.S. democracy.

As juniors taking Morals and Ethics, they examine philosophical models and evaluate actions 
that can be measured as right or wrong in order to develop their own moral standards that support the CG mission. By analyzing ethical and moral standards, cadets are expected to gain a foundation in how to lead the Coast Guard. In Criminal Justice and Maritime Law Enforcement cadets study the U.S. civilian and military criminal justice system and the legal issues associated with the Coast Guard's law enforcement mission in the maritime environment. They also take courses in information systems which provide training in managing information systems and cyber security. In their senior year, cadets complete senior research projects while applying and strengthening their business competencies, communication, self-leadership, critical thinking, and information literacy skills.

The cadets' involvement in the residential life at the USCGA contributes to their self-leadership and leading others development. By living together and professionally interacting with academic faculty, military staff, and athletic coaches outside the classroom, cadets practice their first leading self and leading others skills. By being involved in athletic competition, student organizations, and clubs, they practice and develop self-leadership skills outside the academic classroom and military training. Only upper class cadets practice leadership skills by becoming leaders of their self-governed organizations and sport or activity clubs. During summer training, cadets apply self-leadership skills in the operational Coast Guard or at the USCGA while preparing and training incoming cadets.

\section{Communication Effectiveness Competencies}

Communication effectiveness relates to the communication of ideas through effective speaking and writing, and persuasive informative presentations. Writing, presentation, and speaking ability is assessed at least once annually through an in-class paper and presentation. These papers and presentations are assessed using a common speech rubric across the Management plan of study. This common rubric facilitates the holistic assessment of the cadet's development over four years, as well as a programmatic assessment of the curriculum.

The primary mechanism for this assessment is the Class of 1959 Writing and Speaking Contest. Occurring annually, cadets are assessed in both their speaking and writing in each of their four years at the Academy. Specific courses have been designated to conduct this assessment: as a fourth class, it occurs in their English Composition and Speech course. as a third class in their Organizational Behavior and Leadership course, as a second class in their Leadership and Organizational Development course, and as a first class in their senior capstone course. Looking closer at the assessment, the rubric is comprised of separate writing and speaking components.

The writing component categorizes cadets as developing, competent, or exemplary in the following three objectives: (1) communicate clearly, precisely, and in a well-organized manner; (2) demonstrate a large and varied vocabulary; and (3) organization. The speaking component also categorizes cadets as developing, competent, or exemplary in the following seven components: (1) demonstrate a large and varied vocabulary; (2) recognize and use a variety of communication forms and styles; (3) use computer technologies for communication; (4) demonstrate organization; (5) use mechanics; (6) relate to the audience; and (7) contribute as a team member (for group presentations).

Each instructor in the Department of Management uses this seven-category rubric to assess a cadet's ability to effectively communicate via so called the Class of 1959 Assignment. In addition to using it just for the assignment, the entire department meets at the end of each semester to conduct a holistic review and assessment of cadets' academic performance within the department. Part of this holistic review involves looking at the assessment rubrics and either validating them or adding amplifying information to them through cadets' performance in other courses or from interactions with academic advisors, coaches, and mentors.

Revisiting the assessment rubrics fosters a great discussion on the cadets' development to categorize their accomplishments. If cadets are "developing," the faculty members create additional courses of action to get them to a baseline level of competent in effective communication. Overall, by using a specific assignment in class to assess both writing and speaking effectiveness, then re-evaluating through a holistic review process, Management faculty are extremely confident that by the time a Management major graduates from the Coast Guard Academy they are accurately assessed and affirmed of their ability to effectively communicate. 


\section{Business Competences}

The USCGA General Plan of Study for Management majors within its ongoing assurance of learning efforts is provided in Figure 3. The Management Department Plan of Study advances professional competences in finance, accounting, economics, management, quantitative analysis, marketing, international issues, legal and social environment issues, and management of information systems. Cadets develop the required business competencies in individual courses with an exception of international issues and quantitative analysis which are infused in a number of courses. Overall, cadets are expected to demonstrate each of the business competencies in a global context while creating informed business solutions and conclusions from ambiguous case studies.

Figure 3. General Plan of Study for the USCGA Management Majors, Class 2019.

MANAGEMENT DEPARTMENT - General Plan of Study

\begin{tabular}{|c|c|c|c|c|c|}
\hline & \multicolumn{3}{|l|}{ Fall Semester } & \multicolumn{2}{|l|}{ Spring Semester } \\
\hline & 4/c (Freshman) Year & Credits & & & Credits \\
\hline 0901 & USCG History & 1.00 & 2123 & Writing About Literature & 3.00 \\
\hline 1116 & Statics \& Engr Dsgn & 3.00 & 3117 & Calculus II & 4.00 \\
\hline 2111 & Eng Comp \& Speech & 3.00 & 4103 & Personal Defense I & 0.25 \\
\hline 2141 & Leaders in U.S. History & 3.00 & 4112 & Prin Fitness/Wellness II & 1.00 \\
\hline 3111 & Calculus I & 4.00 & 5106 & Chemistry II (or Physics I) & 4.00 \\
\hline 4102 & Prin Fitness/Wellness I & 1.00 & 6101 & Fund of Navigation & 3.00 \\
\hline 4111 & Swimming I & 0.25 & 8115 & Macroeconomic Prin & 3.00 \\
\hline \multirow[t]{2}{*}{5102} & Chemistry I & 4.00 & & & \\
\hline & 3/c (Sophomore) Year & Credits & & & Credits \\
\hline 2263 & American Govemment & 3.00 & 1320 & Princ Elec Comm Systems & 3.30 \\
\hline 4222 & Professional Rescuer & 2.00 & 3213 & Probability \& Statistics & 3.00 \\
\hline 5262 & Physics I (or Physics II) & 4.00 & 4204 & Lifetime Sports I: RQB & 0.25 \\
\hline 8201 & Intro to Business & 3.00 & 4214 & Lifetime Sports II: Golf & 0.25 \\
\hline 8211 & Ldrshp \& Org Behavior & 3.00 & 2393 & Morals and Ethics & 4.00 \\
\hline \multirow[t]{4}{*}{8217} & Microeconomic Prin & 3.00 & 6201 & Ships \& Maritime Sys & 3.00 \\
\hline & & & 6202 & Apps in Navigation Lab & 1.00 \\
\hline & & & 8246 & Financial Accounting & 3.00 \\
\hline & 2/c (Junior) Year & Credits & & & Credits \\
\hline 2391 & Criminal Justice & 3.00 & 8342 & Marketing & 3.00 \\
\hline 4303 & Personal Defense II & 0.25 & 4304 & Lifetime Sports III: Tennis & 0.25 \\
\hline 6301 & Maritime Watch Officer & 4.00 & 8349 & Financial Management & 3.00 \\
\hline 8331 & Management Info Sys & 4.00 & 8363 & Ops \& Project Mgmt & 3.30 \\
\hline 8348 & Managerial Accounting & 3.00 & 8366 & Ldrshp \& Org Development & 3.00 \\
\hline \multirow[t]{2}{*}{8357} & Human Resources Mgmt & 3.00 & & Major Area Elective & 3.00 \\
\hline & 1/c (Senior) Year & Credits & & & Credits \\
\hline 2493 & Maritime Law Enfremnt & 3.00 & 5442 & Atmosphere \& Mar Science & 3.00 \\
\hline 6401 & CG Division Officer & 4.00 & 8441 & Legal Environ Bus & 3.00 \\
\hline \multirow[t]{4}{*}{8443} & Strategic Management & 3.00 & 8445 & Public Mgmt Consulting & 3.00 \\
\hline & Major Area Elective & $3.0-4.0$ & & Free Elective & $3.0-4.0$ \\
\hline & Free Elective & $3.0-4.0$ & & Free Elective & $3.0-4.0$ \\
\hline & Physical Education & 0.50 & 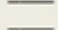 & Physical Education & Note \\
\hline
\end{tabular}

Source: Management Department, USCGA.

Finance and accounting competencies are developed in two full semester courses, Financial Accounting and Managerial Accounting. These two-semester sequence courses expose cadets to the accounting process as a system for exchanging financial information to both internal and external users. Cadets continue the application of basic cost accounting concepts to examine cost information in decision making including different costing systems, cost behavior, and variance analysis.

Economics competence is achieved through courses in Principles of Macroeconomics and Principles of Microeconomics. Cadets develop basic understanding of aggregate economic activity, trade, and policy for economic stability and growth. Concepts are then reinforced by understanding basic analysis of economic decision making within a market economy. Cadets study supply and demand theory as well as public policy to improve market performance. They are also expected to understand how government policies and regulations can improve or distort economic efficiency in a market.

Management competence is developed in several courses including Introduction to Business, Organizational Behavior and Leadership, Strategy, Human Resource Management, and Strategy. Cadets learn about the history and development of management and business including the areas of planning, organizing, and control. Working with local business mentors in the community, cadets study and present entrepreneurial research projects combining basic business competencies. Using leadership as a focus, cadets examine the role of leadership and analyze the relationship between individuals and group dynamics within organizations to achieve management performance effectiveness. Cadets continue to develop knowledge in 
human resource management theory as it pertains to supervisors and workforce managers. Finally, cadets develop management competence as it pertains to the strategic development of policy in the private and public sectors, including an emphasis on environmental analysis and ethics.

Quantitative analysis is primarily developed in the Operations and Project Management course. In this course, cadets study operations and industrial applications to include maintenance and production scheduling, project planning and management. Cadets are expected to reinforce understanding of quantitative analysis through a lab where they demonstrate problem solving skills using manual computations as well as through computerbased applications. Quantitative analysis is also infused in Financial Accounting, Principles of Microeconomics, and Principles Macroeconomics.

Cadets learn about marketing by examining strategic management including the marketing mix, market segmentation, product differentiation, demographics, advertising, promotion, and distribution. Given that USCGA is a military service academy, cadets must understand the role of marketing in governmental organizations. International issues are dispersed in nearly all of the management related courses, but there is a strong emphasis in Principles of Macroeconomics, Introduction to Business, and Operations and Project Management. Cadets gain business competencies from a global to a domestic context.

In Legal Environment of Business, cadets develop business competence in legal and social environment issues. Ethical and social responsibilities are inherent in business decisionmaking; cadets apply this knowledge to case studies and projects. They must understand the principles of business law to include: sources of law, commercial transactions, torts, intellectual property, business entities, employment law and environmental law.

Given the rapid increase in technology and its usage within business platforms to communicate information, cadets develop competence in the management of information systems. In the course, Management of Information Systems, cadets are prepared to lead in a technological environment by learning information management structures, information systems development, computing technology, and security. This knowledge is applied in a lab in conjunction with the lectures.

\section{Critical Thinking Ability}

Critical thinking development is essential to the USCGA leadership program. In May 2007, the USCGA developed and implemented a working definition of critical thinking based on Bloom's taxonomy (Bloom et al., 1971): "Critical Thinking Process is the activity of striving to improve the processes, attitudes, and skills people use while conceptualizing, interpreting, analyzing, applying, synthesizing, and evaluating information" as illustrated in Figure 4.

Figure 4. Graphical Illustration of the USCGA Critical Thinking Process

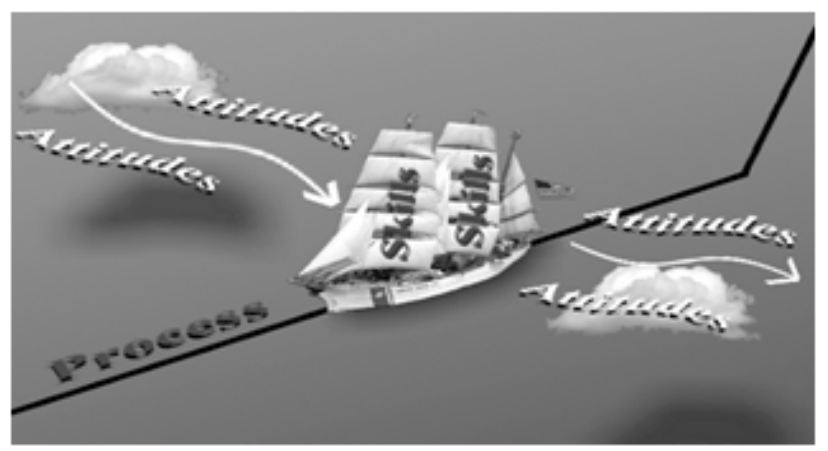

Source: Developed by the USCGA Critical Thinking Committee, 2007.

The USCGA Critical Thinking Process is based on work of Anderson and Krathwohl and its characteristics are illustrated in Figure 5 (Anderson and Krathwohl, 2001). There are six stages used to develop and practice cadets' critical thinking skills. Each stage of the process is important to achieve effective instruction and learning. The model guides students' work via six stages of the critical thinking process that include: Stage 1: Remembering; Stage 2: Understanding; Stage 3: Applying; Stage 4: Analyzing; Stage 5: Evaluating; and Stage 6: Creating. 
Figure 5. The Critical Thinking Process and its Characteristics

\begin{tabular}{|l|l|}
\hline PROCESS \\
\hline REMEMBERING \\
\hline UNDERSTANDING \\
long-term memory.
\end{tabular}

Source: Anderson and Krathwohl (2001, pp. 67-68).

The Academy, and in particular the Department of Management, assess critical thinking skill level using the Watson-Glaser Critical Thinking Appraisal (CTA) at the beginning of freshman year and then at the end of senior year. However, critical thinking development is measured and assessed in each course in order to monitor progression of cadets' critical thinking development. During their freshman and sophomore years cadets master Stage 1: Remembering; Stage 2: Understanding; Stage 3: Applying; and Stage 4: Analyzing and in their junior and senior year, they are required to master Stage 5: Evaluating; and Stage 6: Creating. The performance in each course, depending on the stage of education, is evaluated and assessed based on the critical thinking process as illustrated in Figure 6.

Figure 6. The Critical Thinking Process at the USCGA

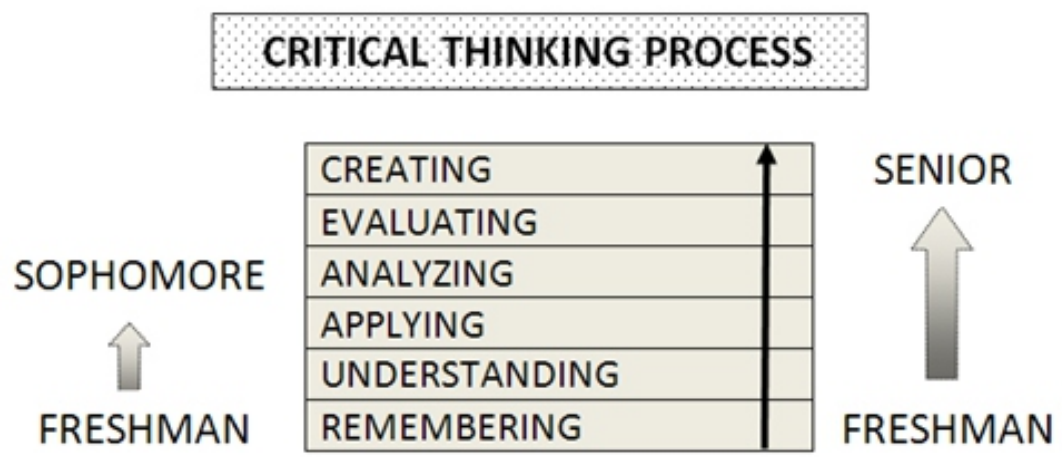

Source: Developed by Management Department, USCGA.

The Management Department believes that an important characteristic of successful learning for critical thinking development is that concepts and topics must relate to real problems and issues that draw upon cadets' experiences and that the practical application of a concept must come before abstract conceptualization is realized. The CGA faculty assigns projects that are based on students' life experience and the purpose of each assignment is clearly thought out to avoid misinterpretation of the written instructions.

\section{Information Literacy Competencies}

The USCGA recognizes that information literacy is a critical element to the success of the CG leaders and the Coast Guard as an organization within the global information society. The USCGA defines information literacy as "the ability to know when there is a need for information, to be able to identify, locate, evaluate and effectively use that information for the issue or problem at hand" based on the National Forum on Information Literacy definition (http://infolit. 
org/definitions/) and has established an information literacy model that is similar to Indiana University model. The model consists of six key components summarized in Figure 7 as: (1) IL Competencies; (2) Current Library Instruction; (3) IL Across the Curriculum; (4) Evidence of Students Learning; (5) Resources for Assessment; and (6) Beyond the Library and facilitates development and mastery of information literacy skills.

Figure 7. The USCGA IL Model

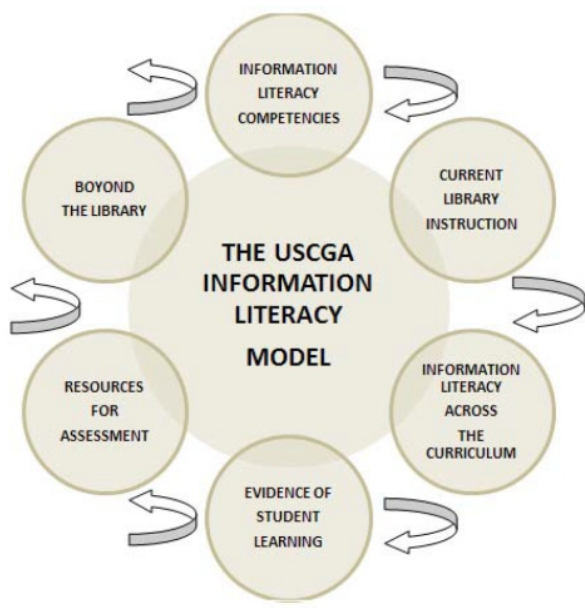

Source: Indiana University https://www.ulib.iupui.edu/research/infolit/niloa_1

The USCGA adopted the six-stage competency model for information literacy initiative that was developed by the American Library Association. As a result, the information literate cadet must: (1) Determine the extent of information needed; (2) Access the needed information effectively and efficiently; (3) Evaluate information and its sources critically; (4) Incorporate selected information into one's knowledge base; (5) Use information effectively to accomplish a specific purpose; and (6) Understand the economic, legal, and social issues surrounding the use of information, and access and use information ethically and legally (Information Literacy Competency Standards for Higher Education. American Library Association, http://www.ala.org). The Management Department IL strategy has been based on mapping IL skills over an entire program.

Incorporating IL across the Management Department curricula requires the collaborative efforts of Management Department faculty, the USCGA librarians, and IT staff. The USCGA librarians assist the Management Department faculty with the evaluation and selection of intellectual and information materials for programs; organize and maintain collections; and provide instruction to cadets. Through lectures, research projects, and written assignments, Management Department faculty establish information literacy that is consciously structured from freshman to senior year. To help meet the goals for improving information literacy outcomes, the Management Department assesses information literacy in selected courses. The goal is to monitor the progress of all cadets during the academic year so that appropriate changes will be made to improve instruction; and identify at the beginning of the academic year those cadets who may need help because of inadequate information literacy skills that are likely to interfere with their ability to conduct information literacy projects. Once fully implemented, a model of information literacy will ensure that information literacy skills are mastered and all graduates are confident, creative, and proficient with information literacy skills.

\section{Conclusions}

The role of leadership has been vital to the development, growth, and success of both private sector and public organizations. The goal of leadership education is to prepare students to effectively lead themselves and their organizations throughout their professional careers. Academic institutions must provide programs that produce leaders who help establish environments that are conducive to revitalization and open-minded organizational culture, innovations, and organizational diversity that in turn help organizations and communities remain competitive and effective.

The USCGA has created a leadership development curriculum and practices that can serve as a model for any undergraduate program interested in preparing students for their individual and 
group leadership responsibilities in both the private and public sector. The leadership education at the USCGA identifies important processes, skills, and opportunities that promote effective leadership development in all students. The program is unique as it suggests methods and activities that can be taught in an undergraduate program within and outside the classroom. The expectations of the curriculum in the Department of Management and the activities associated with them have been closely aligned with the CG vision that is in support of learning and development of leadership and managerial skills. The Management curriculum and training practices are designed to promote awareness and development of leadership at all levels of the undergraduate program and beyond.

The model leadership development program at the USCGA prescribes a specific set of learning goals and instructional activities, strategies, and resources that have been successful in shaping future leaders of the USCG. The leadership educational strategy is unique and based on an approach to self-leadership development that consists of: developing knowledge of self and others; defining self-leadership; developing self-leadership skills and practices; and applying self-leadership through service that must be supplemented with the development of other learning goals that include: information literacy, communication skills, business competencies, and critical thinking skills. The USCGA leadership model stresses the training of leaders who are ethically, intellectually, and professionally prepared to serve as officers in the USCG. Aspects of this model can be adopted by other academic institutions as they strive towards preparing future leaders. 


\section{References}

Brown, L., \& Posner, B. (2001).Exploring the relationship between learning and leadership. Leadership and Organization Development Journal, 22, 274-280.doi: 10.1108/01437730110403204

Houghton, J. D., \& Neck, C. P. (2002). The Revised self-leadership questionnaire: Testing a hierarchical factor structure for self-leadership. Journal of Managerial Psychology, 17, 672-691. doi: $10.1108 / 02683940210450484$

Kaiser, R. B., Hogan, R., \& Craig, S. B. (2008).Leadership and the fate of organizations. American Psychologist, 63, 96-110.doi: 10.1037/0003-066X.63.2.96

Kouzes, J. M., \& Posner, B. Z. (2011). Leadership begins with an inner journey. Leader To Leader, 2011(60), 22-27.doi: 10.1002/ltl.464

Maellaro, R. (2013). The learning journal bridge: From classroom concepts to leadership practices. Journal of Leadership Education, 12(1), 234 -244.

Neck, C. P. (1996).Thought self-leadership: A self-regulatory approach to overcoming resistance to organizational change. International Journal of Organizational Analysis, 4, 202-216. doi: 10.1108/eb028849

Northouse, P.G. (2007). Leadership: Theory and Practice. 4th Edition, Sage Publications, London.

Papalexandris, N., \& Galanaki, E. (2009).Leadership's impact on employee engagement. Leadership \& Organization Development Journal, 30(4), 365-385.doi: 10.1108/01437730910961685

Prussia, G. E., Anderson, J. S., \& Manz, C. C. (1998). Self-leadership and performance outcomes: The mediating influence of self-efficacy. Journal of Organizational Behavior, 19, 523-538. doi:10.1002/(SICl)1099-1379

Sowcik, M., \& Allen.S.A. (2013).Getting down to business: a look at leadership education in business schools. Journal of Leadership Education, 12(3), 57-75.

Stogdill, R. M., \& Bass, B. M. (1981). Stogdill's handbook of leadership: A survey of theory and research. New York: The Free Press.

Tarabishy A, Solomon G, Fernald Jr, L.W., \& Sashkin. M. (2005). The entrepreneurial leader's impact on the organization's performance in dynamic markets. Journal of Private Equity, Vol 8, No. 4, pp. 20-29.doi: 10.3905/jpe.2005.580519

Taylor,R.L. \& Rosenbach, W.E. (2005). In Pursuit of Excellence, 5th Ed. West view Press, 2005

Thayer, L. (1988). Leadership/communication: A critical review and a modest proposal. In G. M. Goldhaber \& G. A. Barnett (Eds.), Handbook of organizational communication (pp. 231-263). Norwood, $\mathrm{NJ}$ :Ablex.

Uhl-Bien, M., Marion, R., \& McKelvey, B. (2007). Complexity leadership theory: Shifting leadership from the industrial age to the knowledge era. Leadership Quarterly, 18, 298-318. 